\title{
KONTRIBUSI PERBANKAN SYARIAH TERHADAP PERTUMBUHAN EKONOMI \\ DI KABUPATEN SAMBAS
}

\author{
Sri Deti \\ Sabri Samin \\ Amiruddin \\ Kasjim Salenda \\ Dosen Institut Agama Islam Sultan Muhammad Syafiuddin Sambas \\ sridety@yahoo.com
}

\begin{abstract}
Abstrak: Penelitian ini mengkaji tentang kontribusi dana pihak ketiga dan pembiayaan perbankan syariah terhadap pertumbuhan ekonomi (Produk Domestik Regional Bruto) Kabupaten Sambas. Penelitian ini merupakan penelitian kuantitatif dengan jenis penelitian applied research yang bersifat eksplanatif dengan pendekatan scientific (ilmiah-empiris). Hasil dari penelitian ini diketahui kontribusi dana pihak ketiga (DPK) terhadap pertumbuhan ekonomi (Produk Domestik Regional Bruto) Kabupaten Sambas adalah sebesar $0.64 \%$. Angka tersebut dapat dikatakan sangat kecil jika dibandingkan dengan kontribusi dana pihak ketiga yang dapat dihimpun oleh perbankan konvensional yaitu sebesar $27.02 \%$. Demikian juga halnya dengan kontribusi pembiayaan terhadap pertumbuhan ekonomi (Produk Domestik Regional Bruto) Kabupaten Sambas, juga menunjukkan angka yang relatif kecil yaitu sebesar $1.17 \%$, jauh dibawah kontribusi pembiayaan yang berhasil disalurkan oleh perbankan konvensional yaitu sebesar $34.39 \%$. Secara umum kontribusi perbankan syariah melalui total dana pihak ketiga (DPK) dan total pembiayaan terhadap pertumbuhan ekonomi (Produk Domestik Regional Bruto) Kabupaten Sambas hanya sebesar $1.81 \%$ jauh dibawah kontribusi dana pihak ketiga (DPK) dan pembiayaan perbankan konvensional yaitu sebesar $61.41 \%$.

Sebagai implikasi diharapkan agar hasil penelitian ini dapat menjadi bahan pertimbangan pihak perbankan syariah dalam mengambil keputusan terutama dalam mengoptimalkan penghimpunan dana pihak ketiga dan penyaluran pembiayaan, sehingga dapat berkontribusi terhadap pertumbuhan di Kabupaten Sambas. Serta dapat memanfaatkan faktor pendukung secara maksimal dan meminimalisir faktor penghambat agar dapat meningkatkan total dana pihak ketiga dan pembiayaan. Selain itu dapat meningkatkan hubungan kerjasama yang saling menguntungkan dengan berbagai pihak agar kehadiran perbankan syariah dapat memberikan kontribusi terhadap laju pertumbuhan ekonomi di Kabupaten Sambas.
\end{abstract}

\section{Keywords: Perbankan Syariah, Pertumbuhan Ekonomi.}

\section{PENDAHULUAN}

Sektor keuangan memainkan peran penting dalam mendorong pertumbuhan berbagai sektor ekonomi. Ini dikarenakan lembaga perbankan mampu memobilisasi surplus modal dari pihak ketiga untuk diinvestasikan ke berbagai sektor ekonomi yang membutuhkan pembiayaan. Ketika sektor keuangan bertumbuh secara baik maka akan semakin banyak sumber pembiayaan yang dapat dialokasikan ke sektor-sektor produktif dan akan semakin bertambah pembangunan fisik modal yang bisa diciptakan yang nantinya akan berkontribusi positif terhadap pertumbuhan ekonomi. Pertumbuhan dan kinerja positif sektor keuangan akan berkorelasi positif terhadap kinerja ekonomi suatu daerah. Sektor keuangan bisa menjadi sumber utama pertumbuhan sektor riil ekonomi. Semakin banyak alokasi dana pihak ketiga perbankan yang dialokasikan pada sektor- 
sektor riil maka akan semakin berkurang tingkat pengangguran dan kemiskinan dalam sebuah perekonomian. ${ }^{1}$

Salah satu ciri utama perbankan syariah yang berdampak positif terhadap pertumbuhan sektor riil dan ekonomi adalah lembaga keuangan syariah lebih menekankan pada peningkatan produktivitas. Lembaga keuangan syariah adalah lembaga keuangan yang menekankan konsep asset \& production based system (sistem berbasis aset dan produksi) sebagai ide utamanya. Mud\{ha>rabah dan musya>rakah adalah cerminan utama dari ide tersebut, sebagaimana firman Allah dalam QS S $\{a>d$ $38: 24$

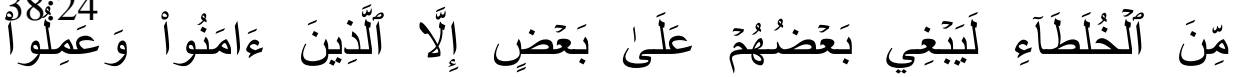

Terjemahnya:

"Dan, sesungguhnya kebanyakan dari orang-orang yang berserikat itu sebagian mereka berbuat zalim kepada sebagian yang lain kecuali orang yang beriman dan mengerjakan amal saleh".

Melalui pola pembiayaan seperti itu maka sektor riil dan sektor keuangan akan bergerak secara seimbang. Akibatnya semakin tumbuh perbankan syariah maka akan semakin besar kontribusinya terhadap kinerja dan pertumbuhan ekonomi. Jumlah kemiskinan dan pengangguran secara langsung akan teratasi melalui kinerja ekonomi yang baik. ${ }^{3}$ Dengan demikian, berinvestasi pada perbankan syariah tidak hanya memberikan keuntungan pada orang yang memiliki kelebihan dana namun juga menguntungkan pihak-pihak yang membutuhkan dana dalam bentuk pembiayaan syariah, dan yang jauh lebih penting keuntungan terbesar yang dapat diperoleh oleh seseorang ketika berinvestasi pada perbankan syariah yaitu sebagaimana firman Allah dalam. Q \& al-Baqarah 2:261.

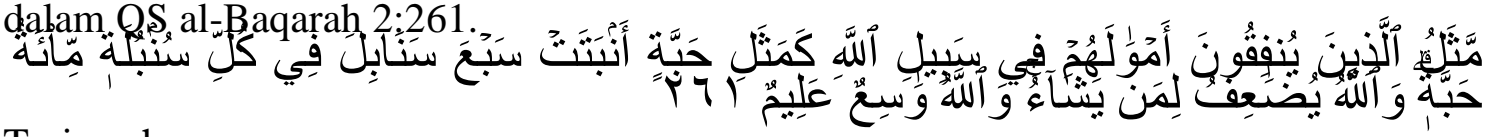

Terjemahnya:

"Perumpamaan orang yang menafkahkan hartanya dijalan Allah, seperti sebutir benih yang tumbuh menjadi tujuh tangkai, yang setiap tangkainya terdiri dari seratus biji. Allah melipatgandakan pahala bagi yang Ia kehendaki. Allah Maha luas lagi Maha Mengetahui.",

Ayat tersebut menjelaskan bahwa Allah menghidupkan negeri yang telah hancur berantakan, dan dikemukakan bahwa membangun dunia dan kemakmurannya mengharuskan adanya manusia yang hidup, tinggal, bergerak, giat dan berusaha. Manusia tidak dapat memenuhi semua kebutuhannya, ia harus bantu membantu, saling lengkap-melengkapi, dan karena itu pula mereka harus beragam dan berbeda-beda agar mereka saling membutuhkan, yang kuat membantu yang lemah. Ayat ini berpesan kepada yang memiliki kelebihan dana agar tidak merasa berat membantu, karena apa yang dinafkahkan akan tumbuh berkembang dengan berlipat ganda. ${ }^{5}$ Hal tersebut sejalan dengan fungsi perbankan dimana lembaga perbankan menjadi intermediasi antara pihak yang memiliki kelebihan dana dengan pihak yang kekurangan dana, dalam hal ini kekurangan modal usaha yang dapat dipenuhi melalui pembiayaan pada perbankan syariah.

Kehadiran lembaga perbankan khususnya perbankan syariah sebagai lembaga yang menghimpun dan menyalurkan dana kepada pihak ketiga sangat dibutuhkan, dalam upaya menggerakkan roda perekonomian di Kalimantan Barat. Dari segi jumlah

\footnotetext{
${ }^{1}$ Ali Rama, "Analisis Kontribusi Perbankan Syariah terhadap Pertumbuhan Ekonomi Indonesia". http://lisensiuinjkt.file.wordpress.com. (14 Juli 2015), h. 2.

${ }^{2}$ Kementerian Agama RI, Al-Qur'an dan Terjemahnya (Yogyakarta: UII Press, 1999), h. 811.

${ }^{3}$ Ali Rama, "Analisis Kontribusi Perbankan Syariah terhadap Pertumbuhan Ekonomi Indonesia", h. 3.

${ }^{4}$ Kementerian Agama RI, Al-Qur'an dan Terjemahnya, h. 77.

${ }^{5}$ M. Quraish Shihab, Tafsir Al-Mishbah: Pesan Kesan dan Keserasian Al-Qur'an (Jakarta: Lentera Hati, 2002), h. 565-567.
} 
kantor, bank syariah yang ada di Kalimantan Barat pada tahun 2017 berjumlah 9 kantor cabang, 13 kantor cabang pembantu dan 1 kantor kas serta 65 kantor layanan syariah dari unit usaha syariah. Sementara dana yang berhasil dihimpun baik dalam bentuk giro, deposito dan tabungan mengalami peningkatan, dimana pada tahun 2012 dana yang dihimpun mencapai 1,315 trilyun rupiah naik menjadi 2,208 trilyun rupiah ditahun 2016. Sedangkan dana yang disalurkan ke berbagai sektor ekonomi melalui pembiayaan syariah juga mengalami kenaikan, dimana pada tahun 2012 pembiayaan yang disalurkan sebesar 1,740 trilyun rupiah naik menjadi 3,757 trilyun rupiah pada tahun $2016^{6}$

Meski terus menunjukkan perkembangan yang baik, namun perkembangan perbankan syariah di Kalimantan Barat masih tergolong kecil, terlebih lagi pada tingkat Kabupaten. Sebagai contoh di Kabupaten Sambas kehadiran perbankan syariah sangat diharapkan terutama oleh masyarakat muslim, melalui pertimbangan dari berbagai pihak hingga akhirnya pada tanggal 12 Januari 2011 PT Bank Syariah Mandiri diresmikan oleh Bupati Sambas Ir. H. Burhanuddin A Rasid, kemudian menyusul BPD Kalbar Syariah pada akhir tahun 2011, dan dilanjutkan oleh Bank Muamalat pada akhir tahun 2012. ${ }^{7}$ Perkembangan perbankan syariah di Kabupaten Sambas dapat dilihat dari perkembangan total asset, dana pikah ketiga dan jumlah pembiayaan yang disalurkan kepada masyarakat di Kabupaten Sambas. Adapun perkembangan tersebut dapat dilihat pada table berikut:

Tabel 1.Total Aset, Dana Pihak Ketiga dan Pembiayaan Bank Umum Syariah dan Unit Usaha Syariah di Kabupaten Sambas

\begin{tabular}{|l|c|c|c|c|c|c|}
\hline \multicolumn{1}{|c|}{ Indikator } & $\mathbf{2 0 1 2}^{*}$ & $\mathbf{2 0 1 3}^{*}$ & $\mathbf{2 0 1 4} *$ & $\mathbf{2 0 1 5}$ & $\mathbf{2 0 1 6}$ & $\mathbf{2 0 1 7}$ \\
\hline Aset & - & - & - & 65 & 121 & 127 \\
\hline DPK & 27 & 29 & 34 & 41 & 58 & 124 \\
\hline Pembiayaan & 44 & 63 & 57 & 62 & 122 & 38 \\
\hline FDR & $160,44 \%$ & $220,97 \%$ & $168,61 \%$ & $150,92 \%$ & $210,40 \%$ & 327,06 \\
\hline
\end{tabular}

Sumber: Statistik Perbankan Syariah Indonesia 2012-2017

*Data total aset tidak tersedia

Tujuan pendirian perbankan syariah bukan hanya untuk keuntungan perusahaan tetapi juga berorientasi untuk menciptakan kesejahteraan di masyarakat dan akhirnya dapat meningkatkan pertumbuhan ekonomi di Kabupaten Sambas. Pertumbuhan ekonomi pada suatu daerah adalah suatu kondisi terjadinya perkembangan Produk Domestik Regional Bruto yang mencerminkan adanya pertumbuhan output per kapita dan meningkatnya standar hidup masyarakat. Hal itu berarti pertumbuhan ekonomi dapat dilihat dari pertumbuhan Produk Domestik Regional Bruto riil yang dihasilkan suatu daerah pada periode waktu tertentu. ${ }^{8}$ Produk Domestik Regional Bruto merupakan bagian dari Produk Domestik Bruto, sehingga jika terjadi perubahan Produk Domestik Regional Bruto ditingkat regional akan berpengaruh terhadap Produk Domestik Bruto atau sebaliknya.

${ }^{6}$ Bank Indonesia, "Statistik Perbankan Syariah", Publikasi desember 2012 dan Otoritas Jasa Keuangan, "Statistik Perbankan Syariah”, Publikasi desember 2016.

${ }^{7}$ Pada bulan April 2016 Bank Muamalat di Kabupaten Sambas dinyatakan ditutup.

${ }^{8}$ H. Saberan, Produk Domestik Regional Bruto (Jakarta: Rajawali, 2002), h. 5. 
Gambar 1. Laju Pertumbuhan Ekonomi Kabupaten Sambas Tahun 2009 - 2017

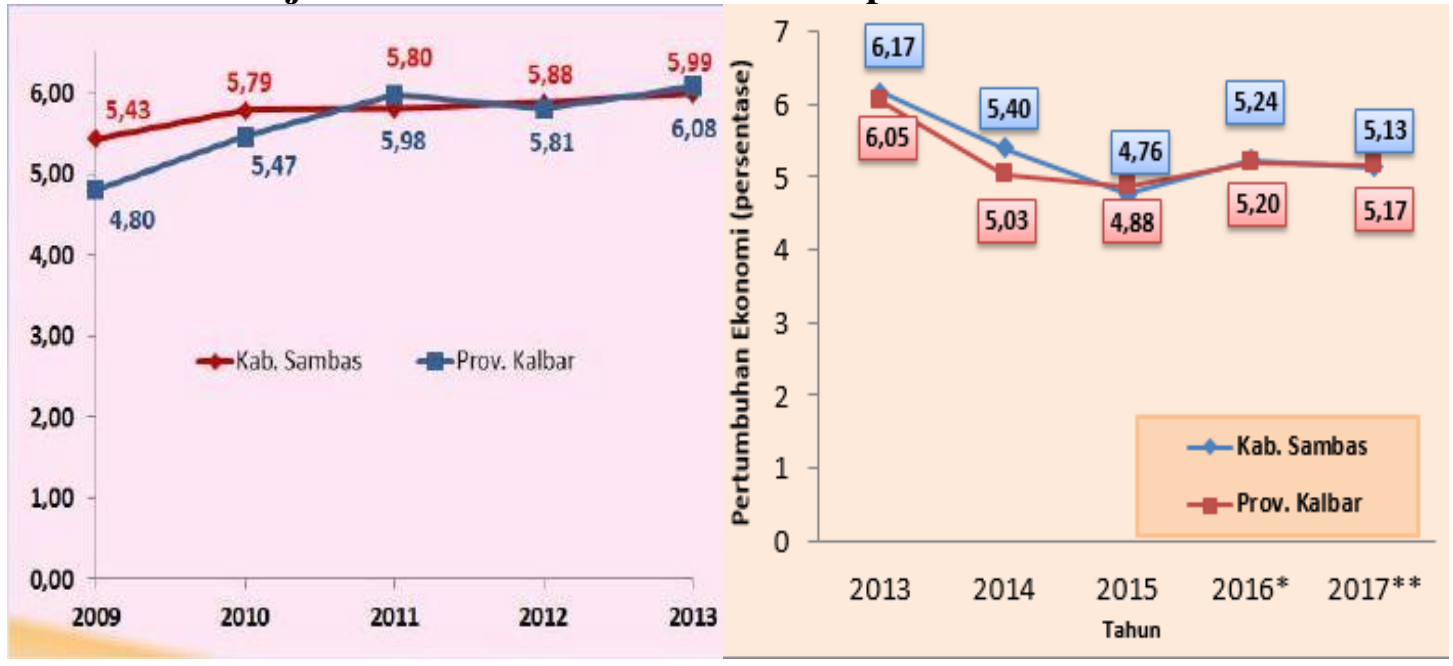

Catatan : *angka sementara, **angka sangat sementara

Berdasarkan gambar tersebut terlihat bahwa laju pertumbuhan ekonomi Kabupaten Sambas selama kurun waktu sembilan tahun stagnasi dilevel lima persen. Pada tahun ketiga kehadiran perbankan syariah di Kabupaten Sambas yaitu tahun 2013 laju pertumbuhan ekonomi sedikit meningkat pada level enam, namun kembali turun pada tahun 2014 bahkan semakin menurun di tahun 2015, dan hingga tahun 2017 masih tetap berada dilevel lima. Hal tersebut merupkan cerminan bahwa kehadiran perbankan syariah pada awal tahun 2011 hingga tahun ketujuh kehadirannya di Kabupaten Sambas tidak terlalu berengaruh terhadap laju pertumbuhan ekonomi. Kondisi tersebut berbanding terbalik dengan harapan dari berbagai pihak pada waktu awal-awal berdirinya perbankan syariah di Kabupaten Sambas, dimana mayoritas penduduk Kabupaten Sambas yang beragama muslim diharapkan menjadi sebuah peluang besar bagi perbankan syariah untuk menjadi penggerak roda perekonomian di Kabupaten Sambas.

Tanpa melakukan upaya yang intensif dan terpadu perbankan syariah sebagai pendatang baru dalam dunia perbankan di Kabupaten Sambas tidak akan mampu memberikan kontribusi yang besar terhadap laju pertumbuhan ekonomidi Kabupaten Sambas, selain itu juga tidak akan bisa bersaing dengan perbankan konvensional yang telah lebih dahulu mampu merebut hati dan kepercayaan masyarakat Kabupaten Sambas. Hal tersebut terbukti dari kasus bank Muamalat, dimana pada bulan April tahun 2016 bank Muamalat yang baru berdiri pada akhir tahun 2012 dinyatakan ditutup dan ditarik ke Provinsi. Hal tersebut merupakan cerminan bahwa pertumbuhan perbankan syariah di Kabupaten Sambas seperti berjalan di tempat bahkan mengalami kemunduran. Namun demikian, tidak dapat dipungkiri kedua perbankan syariah yang masih tetap beroperasional hingga sekarang akan tetap memberikan kontribusi di dalam menggerakkan perekonomiam masyarakat Kabupaten Sambas dan pada akhirnya akan berimbas pada pertumbuhan ekonomi Kabupaten Sambas. Berbagai fenomena ekonomi yang terjadi di Kabupaten Sambas menjadi salah satu alasan penelitian ini dilakukan. Melalui penelitian ini akan diketahui sejauh mana kehadiran perbankan syariah di Kabupaten Sambas yang baru hadir selama kurang lebih tujuh tahun terakhir mampu berkontribusi terhadap pertumbuhan ekonomi di Kabupaten Sambas melalui penghimpunan dana pihak ketiga dan pembiayaan yang disalurkan kepada masyarakat.

\section{KAJIAN TEORETIS}

\section{A. Prinsip-Prinsip Bank Syariah}


Kegiatan operasional bank syariah haruslah berlandaskan prinsip syariah yaitu berdasarkan kepada Al-Qur'an dan hadist, sehingga bank tidak mengandalkan bunga melainkan bagi hasil. Dalam keuangan syariah harus pula dipenuhi ketentuan menghindari riba, gharar dan maysir, objek dan keseluruhan proses investasi harus halal, serta menjamin terlaksananya konsep kemaslahatan dalam menjalankan setiap aktivitas. Falsafah dasar beroperasinya bank syariah yang menjiwai seluruh hubungan transaksinya berprinsip pada tiga hal yaitu efisiensi, keadilan, dan kebersamaan. Efisiensi mengacu pada prinsip saling membantu secara sinergis untuk memperoleh keuntungan/margin sebesar mungkin. Keadilan mengacu pada hubungan yang tidak dicurangi, ikhlas, dengan persetujuan yang matang atas proporsi masukan dan keluarannya. Kebersamaan mengacu pada prinsip saling menawarkan bantuan dan nasihat untuk saling meningkatkan produktivitas.'

Selain itu dalam kegiatan usaha atau kegiatan operasional perbankan syariah menganut tiga prinsip utama yaitu: $:^{10}$

a. Prinsip Keadilan

Prinsip ini tercermin dari penerapan imbalan atas dasar bagi hasil dan pengambilan margin keuntungan yang disepakati bersama antara bank dan nasabah

b. Prinsip Kesederajatan

Bank syariah menempatkan nasabah penyimpan dana, nasabah pengguna dana, maupun bank pada kedudukan yang sama dan sederajat. Hal ini tercermin dalam hak, kewajiban, risiko dan keuntungan yang berimbang diantara nasabah penyimpan dana, nasabah pengguna dana maupun bank.

c. Prinsip Ketentraman

Produk-produk bank syariah telah sesuai dengan prinsip dan kaidah mu'amalah Islam (halal), antara lain ada unsur riba dan menerapkan zakaat harta. Dengan demikian nasabah merasakan ketentraman lahir maupun batin.

Berdasarkan pada 3 (tiga) prinsip utama tersebut, maka di dalam kegiatan pelayanan kepada masyarakat bank syariah menerapkan prinsip-prinsip dasar sebagai berikut: ${ }^{11}$

a. Prinsip Titipan atau Simpanan (Depository)

Prinsip titipan atau simpanan (wadi'ah) dapat diartikan sebagai titipan murni dari satu pihak ke pihak lain, baik individu maupun badan hukum yang harus dijaga dan dikembalikan kapan saja penyimpan menghendaki. Atau dengan kata lain sebagai transaksi penitipan barang/uang antara pihak yang mempunyai barang/uang dengan pihak yang diberi kepercayaan dengan tujuan untuk menjaga keselamatan, keamanan, serta keutuhan barang/uang. ${ }^{12}$

b. Prinsip Bagi Hasil (Profit Sharing)

Prinsip bagi hasil adalah suatu prinsip yang meliputi tatacara pembagian hasil usaha antara penyedia dana dengan pengelola dana dan tidak bertentangan dengan prinsip-prinsip syariah.

c. Prinsip Jual Beli (Sale and Purchase)

Prinsip jual beli merupakan suatu sistem yang menerapkan tata cara jual beli, dimana bank akan membeli terlebih dahulu barang yang dibutuhkan atau menunjuk nasabah sebagai agen bank untuk melakukan pembelian barang atas nama bank, kemudian bank menjual barang tersebut kepada nasabah dengan harga sejumlah harg beli ditambah keuntungan.

d. Prinsip Sewa (Operasional Lease and Financial Lease)

\footnotetext{
${ }^{9}$ Edy Wibowo, dkk, Mengapa Memilih Bank Syariah? (Cet. I; Bogor: Ghalia Indonesia, 2005), h. 33 .

${ }^{10}$ Yusdani, "Perbankan Syariah Berbasis Floating Market", Jurnal Millah IV, No.2 (2005): h. 67

${ }^{11}$ Muhammad Syafi'i Antonio, Bank Syariah Dari Teori ke Praktik (Jakarta: Gema Insani Press, 2001), h. 85.

${ }^{12}$ Veithzal Rivai dan Arviyan Arifin, Islamic Banking (Jakarta: Bumi Aksara, 2010), h. 217.
} 
Prinsip sewa merupakan transaksi sewa menyewa barang antara bank dengan nasabah, setelah masa sewa berakhir, barang sewaan dikembalikan kepada pihak bank atau boleh diperjanjikan barang tersebut untuk dijual kepada nasabah penyewa.

\section{e. Prinsip Jasa (Fee Based Services)}

Bank syariah dapat melakukan berbagai pelayanan jasa perbankan kepada nasabah dengan mendapat imbalan atau keuntungan.

\section{B. Dana Pihak Ketiga (DPK)}

Dana Pihak Ketiga (DPK) adalah dana yang diperoleh dari masyarakat, dalam arti masyarakat sebagai individu, perusahaan, pemerintah, rumah tangga, koperasi, yayasan, dan lain-lain baik dalam mata uang rupiah maupun dalam valuta asing. ${ }^{13}$ Menurut Undang-Undang No.10 tahun 1998 tentang Perbankan mengartikan bahwa Simpanan adalah dana yang dipercayakan oleh masyarakat kepada bank berdasarkan perjanjian penyimpanan dana dalam bentuk Giro, Deposito, Sertifikat Deposito, Tabungan dan/atau bentuk lainnya yang dipersamakan dengan itu. ${ }^{14}$ Sumber dana yang diperoleh dari pihak ketiga ini akan memberikan dampak pada kemampuan perbankan dalam memenuhi skala dan volume transaksi yang pada akhirnya akan dapat meningkatkan laba.

Sementara dana masyarakat adalah dana-dana yang berasal dari masyarakat, baik perorangan maupun badan usaha, yang diperoleh bank dengan menggunakan berbagai instrumen produk simpanan yang dimiliki oleh bank. Dana masyarakat atau yang sering disebut dengan dana pihak ketiga merupakan dana yang terbesar yang dimiliki oleh bank dan ini sesuai dengan fungsi bank itu sendiri yaitu sebagai penghimpun dana dari pihak-pihak yang kelebihan dana. ${ }^{15}$

Dana pihak ketiga (DPK) adalah dana yang berasal dari masyarakat atau nasabah yang terdiri dari giro, tabungan dan simpanan berjangka, sertifikat deposito dan kewajiban segera lainnya. ${ }^{16}$ Secara teknis yang dimaksud dana pihak ketiga pada perbankan syariah adalah giro wadiah, tabungan wadiah, deposito mudha> rabah. Salah satu sumber dana yang digunakan dalam pembiayaan antara lain dana simpanan atau dana dari nasabah (DPK). Sehingga semakin besar dana pihak ketiga yang tersedia, maka bank syariah akan lebih banyak menawarkan pembiayaan musyärakah.

Pada dasaranya, produk penghimpunan dana dari masyarakat yang dilakukan oleh perbankan syariah hampir sama dengan perbankan konvensional, artinya dalam sistem perbankan syariah dikenal produk-produk berupa giro (demand deposit), tabungan (saving deposit), deposito (time deposit) sebagai sarana untuk menghimpun dana masyarakat. Perbedaannya adalah bahwa dalam sistem perbankan syariah tidak dikenal adanya bunga sebagai kontraprestasi terhadap nasabah deposan, melainkan melalui mekanisme bagi hasil dan bonus yang bergantung pada jenis produk apa yang dipilih oleh nasabah. ${ }^{17}$

\section{Manajemen Dana Bank Syariah}

\footnotetext{
${ }^{13}$ Veithzal Rivai dan Arviyan Arifin, Islamic Banking (Jakarta: Bumi Aksara, 2010), h. 579. Lihat juga Ismail, Manajemen Perbankan: Dari Teori Menuju Aplikasi (Jakarta: Kencana. 2010), h.43.

${ }^{14}$ Republi Indonesia, Undang-Undang No.10 tahun 1998 Perubahan atas Undang-Undang Nomor 7 Tahun 1992 tentang Perbankan, pasal 1, ayat5.

${ }^{15}$ Martono, Bank Lembaga Keuangan Lainnya (Yogyakarta: BPFE UGM, 2003), h. 33.

${ }^{16}$ Slamet Riyadi, Banking Assets And Liability Management (Jakarta: LPFEUI, 2006), h. 20.

${ }^{17}$ Anshori, Perbankan Syariah di Indonesia (Yogyakarta: Gajah Mada University Press. 2007), h.79.
} 
Kunci keberhasilan manajemen bank syariah sangat ditentukan oleh bagaimana bank tersebut dapat merebut hati masyarakat, sehingga peranan bank syariah sebagai financial intermediary dapat berjalan dengan baik. ${ }^{18}$

a. Sistem Manajemen Dana Bank Syariah

Manajemen dana bank syariah merupakan upaya yang dilakukan oleh lembaga perbankan syariah dalam mengelola atau mengatur posisi dana yang diterima dari aktifitas funding untuk disalurkan kepada aktivitas financing, dengan harapan bank tersebut mampu memenuhi kriteria-kriteria likuiditas, rentabilitas, dan solvabilitasnya. Sama seperti bank konvensional, bank Syariah juga mempunyai peran sebagai Lembaga intermediary antara unit-unit ekonomi yang mengalami kelebihan dana (surplus unit) dengan unit-unit lain yang mengalami kekurangan dana (deficit unit). Berbeda dengan bank konvensional, hubungan antara bank syariah dengan nasabahnya bukan hubungan antara debitur dengan kreditur melainkan hubungan kemitraan antara penyandang dana (shahibul al maal) dengan pengelola dana (mudharib). Oleh karena itu, tingkat laba yang diperoleh oleh bank syariah bukan saja berpengaruh terhadap tingkat bagi hasil untuk para pemegang saham, tetapi juga berpengaruh terhadap tingkat bagi hasil yang dapat diberikan kepada nasabah penyimpan dana. Dengan demikian, kemampuan manajemen dalam melaksanakan fungsinya sebagai penyimpan harta, pengusaha dan pengelola investasi yang baik (professional investment manager) akan sangat menentukan kualitas usaha bank syariah sebagai lembaga intermediary dan kemampuan menghasilkan laba. ${ }^{19}$

b. Fungsi Manajemen Dana Bank Syariah berikut: ${ }^{20}$

Dalam menjalankan operasinya bank syariah memiliki empat fungsi sebagai

1) Sebagai penerima amanah untuk melakukan investasi dana-dana yang dipercayakan oleh pemegang rekening investasi/deposan atas dasar prinsip bagi hasil dengan kebijakan investasi bank.

2) Sebagai pengelola investasi atas dana yang dimiliki pemilik dana (shahibul $m a>l)$ sesuai dengan arahan investasi yang dikehendaki oleh pemilik dana.

3) Sebagai penyedia jasa lalu lintas pembayaran dan jasa-jasa lainnya sepanjang tidak bertentangan dengan prinsip syariah.

4) Sebagai pengelola fungsi sosial.

c. Permasalahan Manajemen Dana di Bank Syariah

Berikut ini merupakan pokok-pokok permasalahan manajemen dana bank pada umumnya dan demikian juga halnya yang dihadapi oleh bank syariah, permasalahan tersebut antara lain:

1) Berapa memperoleh dana dan dalam bentuk apa serta dengan biaya yang relative murah.

2) Berapa jumlah dana yang dapat ditanamkan dan dalam bentuk apa untuk memperoleh pendapatan yang optimal.

3) Berapa besarnya dividen yang dibayarkan yang dapat memuaskan pemilik/pendiri dan laba ditahan yang memadai untuk pertumbuhan bank syariah. $^{2}$

4)

\section{Manajemen Pembiayaan Bank Syariah}

Pembiayaan adalah pendanaan yang diberikan oleh suatu pihak kepada pihak lain untuk mendukung investasi yang telah direncanakan, baik dilakukan sendiri maupun lembaga. ${ }^{22}$ Perbankan syariah sebagai lembaga intermediary harus mampu menyeimbangkan antara penghimpunan dana dan penyalurannya secara proporsional

107.

${ }^{18}$ Muhammad, Manajemen Dana Bank Syariah (Jakarta: PT. RajaGrafindo Persada, 2017), h.

${ }^{19}$ Muhammad, Manajemen Dana Bank Syariah, h. 109-111.

${ }^{20}$ Ascarya, Akad dan Produk Bank Syariah (Jakarta: PT. RajaGrafindo Persada, 2008), h.112

${ }^{21}$ Muhammad, Manajemen Dana Bank Syariah, h. 111.

${ }^{22}$ Veithzal Rivai dan Arviyan Arifin, Islamic Banking, h. 681. 
dalam bentuk pembiayaan kepada masyarakat, baik yang bersifat produktif maupun konsumtif. Pembiayaan secara luas berarti financing yaitu pendanaan yang dikeluarkan untuk mendukung investasi yang telah direncanakan, baik dilakukan sendiri maupun dijalankan oleh orang lain. ${ }^{23}$

a. Fungsi Pembiayaan

Terdapat beberapa fungsi pembiayaan yang diberikan oleh bank syariah kepada masyarakat penerima, diantaranya:

1) Meningkatkan daya guna uang

2) Meningkatkan daya guna barang

3) Meningkatkan peredaran uang

4) Menimbulkan kegairahan berusaha

5) Stabilitas ekonomi

6) Sebagai jembatan untuk meningkatkan pendapatan nasional

7) Sebagai alat hubungan ekonomi internasional.

b. Jenis Pembiayaan

Jenis pembiayaan pada bank syariah dapat diwujudkan dalam bentuk aktiva produktif dan aktiva tidak produktif. Dimana jenis aktiva produktif bank syariah, dapat dialokasikan dalam bentuk pembiayaan sebagai berikut: ${ }^{24}$

1) Pembiayaan dengan prinsip bagi hasil, meliputi:

a) Pembiayaan mudharabah, adalah perjanjian antara pemilik modal (shahibul $m a>l$ ) dan pengelola dana (mudharib) untuk melakukan kegiatan usaha tertentu, dengan pembagian keuntungan antara kedua belah pihak berdasarkan nisbah yang telah disepakati sebelumnya. Aplikasi mudharabah dalam pembiayaan lembaga keuangan syariah terdapat dua jenis, yaitu:

(1) Mudharabah muthlaqah (unrestricted), adalah mudharabah yang shahibul $m a>l$-nya memberikan otoritas sepenuhnya kepada pengelola dana untuk menginvestasikan atau memutar uangnya.

(2) Mudharabah muqayyadah (restricted), adalah mudharabah yang memberikan kesempatan kepada pemilik dana untuk memberi batasan kepada mudharib. Batasan tersebut antara lain meliputi jenis investasi, tempat investasi, serta pihak-pihak yang dibolehkan terlibat dalam investasi. Mudharabah muqayyadah semacam ini adalah mudharabah yang paling umum dipraktekkan oleh lembaga keuangan syariah. Jika pihak pemberi biaya tidak memberikan syarat, maka dikhawatirkan pengelolaan dana atau usaha yang dilakukan oleh mudharib tidak optimal dan tujuan untuk mendapatkan hasil yang akan dibagi tidak tercapai. Mudharabah muqayyadah ini memungkinkan shahibul ma>l memberikan pengawasan yang ekstra terhadap dana yang dikeluarkan.

b) Pembiayaan musyarakah, adalah perjanjian diantara pemilik modal untuk mencampurkan modal mereka pada usaha tertentu, dengan pembagian keuntungan diantara pemilik modal berdasarkan nisbah yang telah disepakati sebelumnya, sedangkan pembagian kerugian ditanggung berdasarkan proporsi modal masingmasing. Perbedaan yang mendasar dari mudharabah dan musyarakah ini dalam hal penanaman modal dan keikutsertaan dalam manajemen.

2) Pembiayaan dengan prinsip jual beli (piutang), meliputi:

a) Pembiayaan murabahah, adalah perjanjian jual beli antara bank dan nasabah dimana pihak perbankan menyediakan barang yang diperlukan oleh nasabah dan kemudian menjualnya kepada nasabah yang bersangkutan sebesar harga perolehan ditambah margin/keuntungan yang disepakati antara bank syariah dan nasabah.

b) Pembiayaan salam, adalah perjanjian jual beli barang dengan cara pemesanan dengan syarat-syarat tertentu dan pembayaran harga terlebih dulu.

\footnotetext{
${ }^{23}$ Muhammad, Manajemen Bank Syariah (Yogyakarta: UPP STIM YKPN, 2011), h.304.

${ }^{24}$ Muhammad, Manajemen Pembiayaan Bank Syariah (Yogyakarta: UPP AMP YKPN, 2002), h. $22-25$.
} 
c) Pembiayaan istishna', adalah perjanjian jual beli dalam bentuk pemesanan pembuatan barang dengan kriteria dan persyaratan tertentu yang disepakati antara pemesan dan penjual.

3) Pembiayaan dengan prinsip sewa, meliputi:

a) Pembiayaan ijarah, adalah akad pemindahan hak guna atas barang dan jasa, melalui pembayaran upah sewa tanpa diikuti dengan pemindahan hak kepemilikan atas barang tersebut.

b) Pembiayaan ijarah muntahiya bit-tamlik, yaitu akad sejenis perpaduan antara kontrak jual beli dan sewa atau lebih tepatnya akad sewa yang diakhiri dengan perpindahan kepemilikan barang dari pihak yang memberikan sewa kepada pihak penyewa. Sifat pemindahan kepemilikan ini yang membedakan dengan ijarah biasa.

Jenis aktiva tidak produktif yang berkaitan dengan aktivitas pembiayaan adalah berbentuk pinjaman qard atau talangan, yaitu penyediaan dana atau tagihan antara bank syariah dengan pihak peminjam yang mewajibkan pihak peminjam melakukan pembayaran sekaligus atau secara cicilan dalam jangka waktu tertentu.

c. Produk Pembiayaan Bank Syariah

Secara garis besar produk pembiayaan bank syariah terbagi ke dalam empat kategori yang dibedakan berdasarkan tujuan penggunaannya, antara lain: ${ }^{25}$

1) Pembiayaan dengan prinsip jual beli

2) Pembiayaan dengan prinsip sewa

3) Pembiayaan dengan prinsip bagi hasil

4) Pembiayaan dengan prinsip akad pelengkap

Pembiayaan dengan prinsip jual beli ditujukan untuk memiliki barang, sedangkan prinsip sewa ditujukan untuk mendapatkan jasa, sementara prinsip bagi hasil digunakan untuk usaha kerja sama yang ditujukan guna mendapatkan barang dan jasa sekaligus.

Sementara berdasarkan sifat penggunaannya, pembiayaan dapat dibagi menjadi dua, yaitu: ${ }^{26}$

1) Pembiayaan produktif, yaitu pembiayaan yang ditujukan untuk keperluan produksi atau untuk memenuhi kebutuhan peningkatan usaha, baik usaha produksi, perdagangan, maupun investasi.

Pembiayaan produktif dapat dibagi menjadi dua, yaitu:

a) Pembiayaan modal kerja, yaitu pembiayaan untuk memenuhi kebutuhan peningkatan produksi dan untuk keperluan perdagangan atau peningkatan (utility of place) dari suatu barang.

b) Pembiayaan investasi, yaitu untuk memenuhi kebutuhan barang-barang modal (capital goods) serta fasilitas-fasilitas yang erat kaitannya dengan itu.

2) Pembiayaan konsumtif, yaitu pembiayaan yang digunakan untuk memenuhi kebutuhan konsumsi yang akan habis digunakan untuk memenuhi kebutuhan.

d. Analisis Pembiayaan Bank Syariah

Analisis pembiayaan merupakan hal penting untuk merealisasikan pembiayaan di bank syariah. Adapun analisis pembiayaan yang dapat dilakukan oleh perbankan syariah antaralain: ${ }^{2}$

1) Menilai kelayakan usaha calon peminjam,

2) Menekan risiko akibat tidak terbayarnya pembiayaan, dan

3) Menghitung kebutuhan pembiayaan yang layak.

Sementara di dalam analisa pembiayaan perbankan syariah dapat melakukan lima pendekatan, yaitu: ${ }^{28}$

1) Pendekatan Jaminan

\footnotetext{
${ }^{25}$ Adiwarman Karim, Bank Islam Analisis Fiqih dan Keuangan (Jakarta: PT.RajaGrafindo Persada, 2004), h. 87.

${ }^{26}$ Muhammad Syafi'i Antonio, Bank Syariah Dari Teori ke Praktik, h. 160-161.

${ }^{27}$ Muhammad, Manajemen Pembiayaan Bank Syariah, h. 59.

${ }^{28}$ Muhammad, Manajemen Bank Syariah, h. 304.
} 
Artinya bank dalam memberikan pembiayaan selalu memperhatikan kuantitas dan kualitas jaminan yang dimiliki oleh peminjam.

2) Pendekatan Karakter

Artinya bank mencermati secara sungguh-sungguh terkait dengan karakter nasabah.

3) Pendekatan Kemampuan Pelunasan

Artinya bank menganalisis kemampuan nasabah untuk melunasi jumlah pembiayaan yang telah diambil.

4) Pendekatan dengan Studi Kelayakan

Artinya bank memperhatikan kelayakan usaha yang dijalankan oleh nasabah peminjam.

5) Pendekatan Fungsi-Fungsi Bank

Arinya bank memperhatikan fungsinya sebagai lembaga intermediary keuangan, yaitu mengatur mekanisme dana yang dikumpulkan denagn dana yang disalurkan.

Secara umum, prinsip analisis pembiayaan pada perbankan syariah didasarkan pada rumus $5 \mathrm{C}$, yaitu: ${ }^{29}$

1) Character, artinya sifat atau karakter nasabah pengambil pinjaman.

2) Capacity, artinya kemampuan nasabah untuk menjalankan usaha dan mengembalikan pinjaman yang diambil.

3) Capital, artinya besarnya modal yang diperlukan peminjam.

4) Collateral, artinya jaminan yang telah dimiliki yang diberikan peminjam kepada bank.

5) Condition, artinya keadaan usaha atau nasabah prospek atau tidak.

Prinsip 5C tersebut terkadang ditambahkan dengan 1C, yaitu Constraint artinya hambatan-hambatan yang mungkin mengganggu proses usaha. Untuk bank syariah, dasar analisis 5C belumlah cukup. Sehingga perlu memperhatikan kondisi sifat Amanah, Kejujuran, dan Kepercayaan dari masing-masing nasabah.

e. Permasalahan-Permasalahan Pembiayaan pada Bank Syariah

1) Intermediasi Bank Syariah

Bank syariah yang berfungsi sebagai intermediator yang memfasilitasi perdagangan barang dan jasa dengan bertindak sebagai perantara bagi para pelaku transaksi. Para pemberi pinjaman (bank) akan mencari peminjam potensial dan meneliti proposal nasabah, merancang kontrak keuangan yang sesuai, memonitor perilaku peminjam, dan melakukan berbagai hal agar syarat pembayaran terpenuhi. Di pasar keuangan yang telah maju, semua hal itu tidak menjadi persoalan meskipun ada beberapa hal lain yang mesti dihadapi, seperti biaya transaksi, risiko kesalahan penyeleksian karena informasi asimetris (atau tersembunyi), persoalan insentif, dan moral hazard (kejahatan moral pada dasarnya merupakan tindakan negatif yang tersembunyi). Dalam praktiknya, biaya transaksi dan masalah informasi ini menjadi problem yang tidak bisa dihindari. ${ }^{30}$

Pada perkembangan berikutnya, muncul kecenderungan baru dalam kajian perbankan yang secara khusus menganalisis alasan keberadaan bank atau, secara lebih abstrak, kondisi seperti apa yang diperlukan agar intermediasi dapat berjalan dan bagaimana bentuknya. Menurut "teori intermediasi keuangan", beberapa faktor, seperti biaya transaksi, masalah informasi yang tidak lengkap, dan isyarat pasar merupakan faktor yang sangat penting. Maksudnya, kehadiran bank dan perannya sebagai intermediator harus dijelaskan, dan kedudukannya termasuk dalam biaya transaksi atau yang disebut "biaya informasi".

\footnotetext{
${ }^{29}$ Muhammad, Manajemen Bank Syariah, h. 305.

${ }^{30}$ Mervyn K. Lewis dan Latifa M. Algaoud, Perbankan Syari'ah: Prinsip, Praktik, dan Prospek, trj. Burhan Subrata (Jakarta: Serambi Ilmu Semesta, 2007), h. 88.

${ }^{31}$ Mervyn K. Lewis dan Latifa M. Algaoud, Perbankan Syari'ah: Prinsip, Praktik, dan Prospek, trj. Burhan Subrata (Jakarta: Serambi Ilmu Semesta, 2007), h. 91.
} 
Di pasar uang, nilai sebuah promes keuangan (financial promise) bagi seorang pemberi pinjaman potensial tergantung pada watak individu yang mengeluarkan promesnya (kejujuran, prospeknya di masa depan, dan sebagainya) disertai pengetahuan tentang berbagai kemungkinan yang akan terjadi di masa depan yang dapat mempengaruhi nilai promes itu. Menurut Arrow-Debreu, individu bisa melunasi pinjamannya tergantung pada keadaan lingkungan yang tidak berada di bawah kendalinya. Namun, masalah insentif dihilangkan agar individu tidak dapat memepengaruhi keadaan itu. Transaksi ini pun terhindar dari risiko adverse selection (tidak tepat dalam menyeleksi) yang mungkin dilakukan pembuat promes. ${ }^{32}$

\section{2) Internal dan Ekternal Bank Syariah}

Salah satu penyumbang pendapatan terbesar bagi bank syariah adalah dengan menjalankan aktivitas pembiayaan. Ada banyak faktor yang mempengaruhi besar kecilnya pembiayaan yang disalurkan oleh bank syariah, baik faktor eksternal maupun internal bank syariah sendiri. Faktor internal bank syariah biasanya diwakili oleh kondisi keuangan, dalam hal ini melalui laporan keuangan yang dikeluarkan atau dipublikasikan oleh bank syariah baik bulanan maupun tahunan. Sementara faktor ekternal bank syariah biasanya diwakili oleh tingkat bagi hasil (return) atau ekspektasi keuntungan yang diperoleh bank syariah.

\section{E. Konsep Pertumbuhan Ekonomi}

Pertumbuhan ekonomi modern mengacu kepada perkembangan negara maju di Eropa, menurut Simon Kuznets sabagaimana dikutip oleh Jhingan mendefinisikan pertumbuhan ekonomi sebagai kenaikan jangka panjang dalam kemampuan suatu negara untuk menyediakan semakin banyak jenis barang-barang ekonomi kepada penduduknya, kemampuan ini tumbuh sesuai dengan kemajuan teknologi serta penyesuaian kelembagaan dan ideologi. Definisi tersebut memiliki tiga komponen yaitu pertama, pertumbuhan ekonomi suatu bangsa terlihat dari meningkatnya secara terus menerus persediaan barang, kedua, teknologi maju merupakan faktor dalam pertumbuhan ekonomi yang menentukan derajat pertumbuhan kemampuan dalam penyediaan aneka macam barang kepada penduduk, ketiga, penggunaan teknologi secara luas dan efisien memerlukan adanya penyesuaian dibidang kelembagaan dan ideologi sehingga inovasi yang dihasilkan oleh ilmu pengetahuan umat manusia dapat dimanfaatkan secara tepat. ${ }^{33}$

Berdasarkan penjelasan tersebut tergambar jelas bahwa pertumbuhan ekonomi modern merupakan tolakukur pertumbuhan ekonomi suatu negara, dimana suatu negara atau suatu daerah tidak dapat dikatakan tumbuh jika masih memiliki corak kehidupan pedesaan, pola keluarga besar, buta teknologi bahkan buta huruf. Dengan corak seperti itu tidak akan mungkin suatu daerah dapat memenuhi aneka macam barang kebutuhan penduduknya, dimana laju pertumbuhan penduduk tidak diimbangi dengan peningkatan produktivitas, sehingga perlu adanya upaya untuk meningkatkan pendidikan dan corak kehidupan kearah yang lebih modern.

Selain itu pertumbuhan ekonomi sering direpresentasikan oleh pertumbuhan PDB, Produk nasional Bruto (PNB), PDB perkapita dan pendapatan perkapita. Produktif atau tidaknya sebuah negara dapat dilihat dari kemampuan masyarakatnya dalam menghasilkan barang dan jasa. Kemampuan produksi tersebut dihitung dalam Produk Domestik Bruto (PDB). Bila nilai PDB dari tahun ke tahun mengalami kenaikan, maka ekonomi negara tersebut dikatakan sedang tumbuh dan masyarakatnya relatif produktif.

\footnotetext{
${ }^{32}$ Mervyn K. Lewis dan Latifa M. Algaoud, Perbankan Syari'ah: Prinsip, Praktik, dan Prospek, trj. Burhan Subrata (Jakarta: Serambi Ilmu Semesta, 2007), h. 94.

${ }^{33}$ M.L. Jhingan, The Economics of Development and Planning, terj. D. Guritno, Ekonomi Pembangunan dan Perencanaan (Jakarta: Rajawali Pers, 2016), h. 57.
} 
Sedangkan alat yang tepat dalam mengukur pertumbuhan ekonomi yaitu PDB riil atau dikenal dengan PDB atas dasar harga konstan. Penggunaan harga konstan untuk menghilangkan pengaruh inflasi, sehingga angka PDB yang muncul merupakan nilai riil dari total output barang dan jasa. Dumairy mengungkapkan ada tiga metode mengubah PDB atas harga berlaku menjadi harga konstan. ${ }^{34}$ Pertama, yaitu metode revaluasi. Menurut metode ini, PDB konstan diperoleh dengan menetapkan tahun dasar (based year) yang merupakan tahun di mana perekonomian dalam kondisi stabil. Harga barang, yang diwakili oleh indeks harga konsumen (IHK), pada tahun tersebut digunakan sebagai harga konstan untuk tahun-tahun berikutnya.

Metode kedua adalah ekstrapolasi. Metode ini dilakukan dengan cara memperbarui (updating) nilai tahun dasar sesuai dengan indeks produksi atau tingkat pertumbuhan riil dari tahun sebelumnya. Metode ketiga adalah metode deflasi, dilakukan dengan cara membagi nilai masing-masing tahun dengan harga relatif yang sesuai (indeks harga x 1/100).

Sementara pada tingkat daerah Propinsi atau Kabupaten alat yang digunakan untuk mengukur pertumbuhan ekonomi adalah Produk Domestik Regional Bruto (PDRB). PDRB adalah jumlah nilai tambah barang dan jasa yang dihasilkan dari seluruh sektor perekonomian di suatu wilayah. ${ }^{35}$ Sama seperti PDB penghitungan PDRB juga menggunakan dua macam harga yaitu harga berlaku dan harga konstan, dalam hal ini PDRB Kabupaten Sambas.

PDRB menurut Saberan adalah nilai tambah yang mampu diciptakan dari berbagai aktivitas ekonomi dalam suatu wilayah. Istilah PDRB merupakan gabungan dari empat kata. Pertama adalah produk yang berarti seluruh nilai produksi baik barang maupun jasa. Kedua adalah domestik yang berarti perhitungan nilai produksi yang dihasilkan hanya oleh faktor-faktor produksi yang berada dalam wilayah domestik tanpa melihat apakah faktor produksi tersebut dikuasai oleh penduduk atau bukan. Ketiga adalah regional, artinya perhitungan nilai produksi yang dihasilkan hanya oleh penduduk tanpa memperhatikan apakah faktor produksi yang digunakan berada dalam wilayah domestik atau bukan. Terakhir adalah bruto yang bermakna perhitungan nilai produksi kotor karena masih mengandung biaya penyusutan. ${ }^{36}$

PDRB memiliki perbedaan atas dasar yaitu, (1) PDRB atas dasar harga konstan menggambarkan totalitas dari nilai tambah barang dan jasa yang dihitung menggunakan harga pada satu tahun tertentu (disebut tahun dasar). Dengan menggunakan harga konstan maka perkembangan agregat dari tahun ke tahun semata-mata disebabkan oleh perkembangan riil dan sudah tidak mengandung fluktuasi harga (inflasi atau deflasi). (2) PDRB atas dasar harga berlaku menggambarkan total dari nilai tambah barang dan jasa yang dihitung menggunakan harga berlaku pada tahun berjalan. ${ }^{37}$

Perhitungan PDRB dapat dilakukan dengan menggunakan tiga pendekatan yaitu, pendektan produksi, pedekatan pendapatan dan pendekatan pengeluaran. ${ }^{38}$

\section{a. Pendakatan produksi}

Pada pendekatan produksi, penghitung nilai tambah dari barang dan jasa yang diproduksikan oleh suatu kegiatan ekonomi/sektor ekonomi di daerah tersebut dikurangi biaya antara masing-masing total produksi bruto tiap kegiatan subsektor atau sektor dalam jangka waktu tertentu. Nilai tambah merupakan selisih antara nilai produksi dan nilai biaya antara yaitu bahan baku/penolong dari luar yang dipakai dalam proses produksi.

b. Pendekatan pendapatan

Pada pendekatan pendapatan, nilai tambah dari setiap kegiatan ekonomi diperkirakan dengan menjumlahkan semua balas jasa yang diterima faktor produksi,

${ }^{34}$ Dumairy, Perekonomian Indonesia (Jakarta: Erlangga, 1996), h. 39.

${ }^{35}$ Badan Pusat Statistik, Produk Domestik Regional Bruto (Lapangan Usaha), https://www.bps.go.id/Subjek/view/id/52, (07 Maret 2016).

${ }^{36}$ Saberan, Produk Domestik Regional Bruto (Jakarta: Rajawali, 2002), h.5.

${ }^{37}$ Sudono Sukirno, Pengantar Teori Mikroekonomi (Jakarta: RajaGrafindo Persada, 2003), h.164.

${ }^{38}$ R. Tarigan, Ekonomi Regional: Teori dan Aplikasi (Jakarta: Bumi Aksara. 2005), h.24. 
yaitu upah dan gaji dan surplus usaha, penyusutan, dan pajak tidak langsung neto.pada sektor pemerintahan dan usaha yang sifatnya tidak mencari untung, surplus usaha tidak diperhitungkan. Surplus usaha meliputi bunga yang dibayarkan neto, sewa tanah, dan keuntungan. Metode pendekatan pendapatan banyak dipakai pada sektor jasa, tetapi tidak dibayar setara harga pasar, misalnya sektor pemerintahan. Hal ini disebabkan kurang lengkapnya data dan tidak adanya metode yang akurat yang dapat dipakai dalam mengukur nilai produksi dan biaya antara dari berbagai kegiatan jasa, terutama kegiatan yang tidak mengutip biaya.

\section{c. Pendekatan pengeluaran}

Pendekatan dari segi pengeluaran adalah menjumlahkan nilai penggunaan akhir dari barang dan jasa yang diproduksi di dalam negeri. Jika dilihat dari segi penggunaan maka total penyediaan/produksi barang dan jasa itu digunakan untuk konsumsi rumah tangga, konsumsi lembaga swasta yang tidak mencari untung, konsumsi pemerintah, pembentukan modal tetap bruto (investasi), perubahan stok dan ekspor neto.

\section{F. Faktor-Faktor yang Mempengaruhi Pertumbuhan Ekonomi}

Ada beberapa faktor yang bisa mempengaruhi pertumbuhan ekonomi suatu negara atau wilayah. Para ekonom klasik mengelompokkannya ke dalam tujuh faktor sebagai berikut: ${ }^{39}$

Faktor pertama adalah ketersediaan barang modal. Agar ekonomi mengalami pertumbuhan, maka stok barang modal harus ditambah dengan cara peningkatan investasi. Salah satu upaya dalam meningkatkan investasi adalah dengan menangani faktor-faktor yang memengaruhi tingkat investasi, diantaranya stabilitas politik, pelayanan birokrasi dalam satu pintu, pajak yang rendah, dan lain sebagainya.

Faktor kedua, kualitas tenaga kerja. Khusus di negara sedang berkembang, tenaga kerja (TK) masih merupakan faktor produksi yang sangat dominan. Penambahan tenaga kerja umumnya berpengaruh terhadap peningkatan output. Yang menjadi pertanyaan adalah berapa banyak penambahan TK akan terus meningkatkan output. Selama ada sinergi antara TK dan teknologi, penambahan TK akan memacu pertumbuhan ekonomi. Jumlah TK yang dapat dilibatkan dalam proses produksi akan semakin sedikit bila teknologi yang digunakan makin tinggi atau akan terjadi trade off.

Faktor ketiga yaitu perkembangan teknologi. Kemajuan teknologi makin memperbesar ketimpangan ekonomi antar bangsa, utamanya negara maju dengan negara sedang berkembang. Untuk mengatasi ketimpangan antara tenaga kerja dan teknologi, beberapa ekonom mengajukan konsep berupa teknologi tepat guna. Dengan penggunaan teknologi ini, manusia dapat memanfaatkan secara optimal apa yang ada dalam diri dan lingkungannya. Bahkan kelebihan penggunaan teknologi tepat guna adalah ditekannya pemborosan penggunaan SDA atau energi dalam proses produksi.

Faktor keempat adalah kemampuan finansial. Dalam perekonomian modern, uang memegang peran sentral. Makin banyak uang yang digunakan dalam proses produksi, makin besar output yang dihasilkan. Tetapi dengan jumlah uang yang sama, dapat dihasilkan output yang lebih besar jika penggunaannya efisien. Tingkat efisiensi penggunaan uang sangat ditentukan oleh tingkat efisiensi sistem perbankan. Pembenahan sistem keuangan ini akan memberi sumbangan yang signifikan terhadap pertumbuhan ekonomi.

Faktor kelima yang dapat mendorong pertumbuhan ekonomi yaitu kemampuan manajerial. Manajemen adalah peralatan yang sangat dibutuhkan untuk mengelola perekonomian modern, terutama perekonomian yang sangat mengandalkan mekanisme pasar. Sistem manajemen yang baik, terkadang jauh lebih berguna dibanding barang modal yang banyak, uang yang berlimpah dan teknologi tinggi. Banyak contoh di mana suatu negara yang tidak terlalu mengandalkan teknologi tinggi tapi mampu

\footnotetext{
${ }^{39}$ Prathama Rahardja dan Mandala Manurung, “Teori Ekonomi Makro: Suatu Pengantar”, dalam Zaini Ibrahim, "Kontribusi Perbankan Syariah Terhadap Perekonomian Banten", Jurnal Islamiconomic 6, No.1, (2015): h. 108.
} 
mempertahankan pertumbuhan ekonominya, misalnya Thailand. Dengan potensi pertanian dan keindahan alamnya, Thailand mampu mengelola agribisnis dan sektor pariwisata dengan baik. Bahkan dengan hasil pertaniannya, yaitu beras ketan, Thailand dapat membeli pesawat buatan Indonesia, dengan cara imbal jual (counter trade).

Faktor keenam adalah kemampuan wirausaha (entrepreneurship). Kewirausahaan diartikan sebagai kemampuan dan keberanian mengambil risiko untuk memperoleh keuntungan. Para wirausahawan atau pengusaha harus mempunyai perkiraan yang matang bahwa input yang dikombinasikannya akan menghasilkan barang dan jasa yang dibutuhkan oleh masyarakat, sehingga timbal baliknya akan memberikan keuntungan yang maksimal bagi perusahaan.

Faktor ketujuh yang tidak kalah pentingnya adalah penguasaan informasi. Syarat agar pasar berfungsi sebagai alokasi sumber daya ekonomi yang efisien adalah adanya informasi yang sempurna dan seimbang (perfect and simetric information). Kegagalan pasar merupakan akibat tidak terpenuhinya asumsi ini. Sebab semakin banyak, semakin benar dan semakin berimbang arus informasi, para pelaku ekonomi dapat mengambil keputusan dengan lebih cepat dan lebih baik, sehingga sumber daya ekonomi makin efisien. Dapat dikatakan bahwa penguasaan informasi sangat menunjang pertumbuhan ekonomi.

\section{G. Peran Sektor Perbankan dalam Mendorong Pertumbuhan Ekonomi}

Menurut Pohan dalam konteks perencanaan pembangunan ekonomi secara makro, perekonomian dikelompokkan ke dalam empat sektor yaitu sektor riil, sektor eksternal, sektor pemerintah (fiskal), dan sektor moneter. Keempat sektor tersebut mempunyai hubungan yang saling mempengaruhi, dimana pertumbuhan permintaan agregat yang tercermin pada konsumsi, investasi, dan net ekspor terkait erat dengan pertumbuhan kredit perbankan, aliran modal masuk, pengeluaran pemerintah dan faktor lainnya. ${ }^{40}$ Dengan demikian telah jelas bahwa sektor perbankan mempunyai peran serta dalam perencanaan pembangunan ekonomi, dimana perencanaan pembangunan ekonomi dimulai dengan melakukan proyeksi pertumbuhan ekonomi dengan memperhatikan sektor luar negeri dan potensi anggaran pemerintah. Untuk menganalisa peran sektor perbankan terhadap perkembangan ekonomi terdapat empat jalur yang bisa digunakan. Keempat jalur tersebut dinamakan efek substitusi, efek suku bunga, efek kekayaan, efek ekspektasi masyarakat. ${ }^{41}$

Efek substitusi terjadi karena hukum deminishing marginal utility, yang berlaku pada konsumsi barang dan jasa, berlaku juga pada penggunaan uang. Semakin banyak uang diterima oleh seseorang, semakin kecil nilai tambah kegunaan yang bisa diperoleh orang tersebut atas uang yang diterimanya. Makin banyak uang yang diterima seseorang, akan semakin besar hasrat orang tersebut menukarkan uangnya dengan barang atau jasa yang dapat memberi nilai tambah kegunaan yang lebih besar. Kondisi inilah yang disebut dengan efek substitusi. Efek substitusi menjadi penghubung antara sektor moneter dengan sektor riil. Penambahan jumlah uang beredar di pasar akan meningkatkan konsumsi masyarakat terhadap barang dan jasa. Saat jumlah uang yang dipegang menjadi semakin banyak, masyarakat akan menukarkannya menjadi bentuk lain yang memberi nilai tambah, misalnya dengan membeli barang dan jasa, sehingga konsumsi barang dan jasa akan meningkat. Peningkatan permintaan akan mendorong peningkatan produksi, dan akhirnya sektor riil berjalan semakin cepat.

Peningkatan aktivitas di sektor riil akan meningkatkan pertumbuhan ekonomi dan memperluas kesempatan kerja. Namun, kenaikan produksi tidak akan berlangsung terus-menerus tanpa batas. Pada suatu saat akan mencapai titik jenuh. Bila kapasitas perekonomian mencapai titik jenuh dan kapital yang tersedia menjadi terbatas, perekonomian tidak mampu lagi meningkatkan produksi dan memperluas investasi.

\footnotetext{
${ }^{40}$ Aulia Pohan, Kerangka Kebijakan Moneter dan Implementasinya di Indonesia (Jakarta: PT. RajaGrafindo Persada, 2008), h. 68.

${ }^{41}$ Aulia Pohan, Potret Kebijakan Moneter Indonesia (Jakarta: PT. RajaGrafindo Persada, 2008), h. 5 .
} 
Dampak yang terjadi berikutnya bukan lagi kenaikan produksi melainkan kenaikan harga barang dan jasa, yang dikenal dengan inflasi. Kondisi inilah yang diyakini oleh Milton Friedman bahwa ekspansi moneter dalam jangka panjang tidak akan mendorong pertumbuhan ekonomi dan memperluas kesempatan kerja, tetapi hanya akan meningkatkan inflasi. ${ }^{42}$

Efek suku bunga muncul karena mempengaruhi masyarakat dalam memilih bentuk kekayaan yang ingin dimilikinya, apakah dalam bentuk uang, financial assets, atau benda-benda riil seperti tanah, rumah, emas dan lan sebagainya. Mana yang memberi hasil lebih tinggi akan lebih diminati. Ekspansi moneter selain mendorong masyarakat menukarkan uangnya dengan barang dan jasa dapat juga mendorong masyarakat menukarkan uangnya ke dalam bentuk aset keuangan (financial asset). Preferensi masyarakat untuk membeli aset keuangan mengakibatkan kenaikan hargaharga aset keuangan tersebut yang berarti pula terjadinya penurunan suku bunga dari aset keuangan tersebut. Penurunan suku bunga akan mengurangi biaya modal (cost of capital) dan pada gilirannya akan mendorong kegiatan produksi dan investasi sehingga meningkatkan pertumbuhan ekonomi serta memperluas kesempatan kerja.

Di sisi lain, penurunan suku bunga dapat mendorong perpindahan kapital ke luar negeri atau capital flight, khususnya ke negara di mana tingkat bunganya lebih menguntungkan. Capital flight pada gilirannya akan merugikan neraca pembayaran. Neraca pembayaran dapat mewakili rapor suatu negara. Neraca pembayaran diterjemahkan sebagai suatu catatan sistematis mengenai transaksi ekonomi yang dilakukan penduduk (residen) suatu negara dengan penduduk negara lain (nonresiden) dalam jangka waktu tertentu. Dengan demikian, dalam neraca pembayaran akan tergambar besarnya ekspor, impor, jasa-jasa, dan lalu lintas dari dan ke suatu negara. Dengan melihat neraca pembayaran selintas bisa diketahui kinerja ekonomi eksternal suatu negara. ${ }^{43}$

Kenaikan harga barang atau inflasi, bagi sebagian masyarakat yang memiliki kekayaan dalam bentuk riil seperti tanah, bangunan, emas, dan lain-lain, akan menyebabkan meningkatnya nominal kekayaan yang mereka miliki. Misalnya, tanah yang semula harganya Rp 100 juta, dengan naiknya harga-harga, nilai tanah tersebut meningkat menjadi Rp 120 juta. Secara nominal, kekayaan pemilik tanah mengalami peningkatan. Kenaikan kekayaan nominal ini akan membuat masyarakat merasa dirinya lebih kaya dibandingkan dengan sebelum adanya inflasi. Perasaan tersebut akan mendorong masyarakat untuk meningkatkan konsumsinya. Dalam teori moneter, kondisi di atas dikenal dengan wealth effect atau efek kekayaan yang dampak moneternya sama dengan efek substitusi dan efek suku bunga.

Ekspektasi masyarakat terhadap kenaikan harga pada gilirannya akan mendorong kenaikan suku bunga. Apabila suku bunga meningkat lebih kecil dibandingkan dengan kenaikan harga, secara riil return atas aset keuangan yang dimiliki akan menurun. Penurunan tersebut akan mendorong orang mengalihkan kekayaannnya dari bentuk aset keuangan ke bentuk aset riil. Dengan kondisi demikian, apabila masyarakat atau perusahaan dapat memanfaatkan berbagai informasi atau data moneter dengan baik sehingga dapat memperkirakan inflasi, mereka akan menaikkan harga barang yang diproduksinya. Di sisi lain, para pekerja juga akan meminta upah yang lebih tinggi mendahului kemungkinan inflasi yang mereka perkirakan akan terjadi.

Apabila tindakan antisipasi itu dilakukan oleh sebagian besar masyarakat, tindakan tersebut akan membawa dua implikasi moneter yang sangat penting, yaitu pertama, kebijakan moneter menjadi tidak efektif. Karena kebijakan moneter tidak mengubah sektor riil, yaitu konsumsi, produksi, investasi, dan kesempatan kerja. Hal yang terjadi hanyalah perubahan harga. Kedua, ekspektasi masyarakat terhadap inflasi akan mengakibatkan inflasi yang semula hanya merupakan dugaan, justru menjadi kenyataan.

\footnotetext{
${ }^{42}$ Aulia Pohan, Potret Kebijakan Moneter Indonesia, h. 6.

${ }^{43}$ Aulia Pohan, Potret Kebijakan Moneter Indonesia, h. 7.
} 
Keempat jalur atau efek inilah yang menjadi hubungan sebab akibat antara kebijakan moneter dengan perekonomian secara makro. Relasi yang demikian kompleks ini pula harus menjadi pertimbangan bagi pengambil kebijakan moneter untuk menentukan apa target kebijakan moneter yang akan dituju dan bagaimana strategi pencapaiannya.

\section{III.METODOLOGI PENELITIAN}

Penelitian ini merupakan penelitian kuantitatif deskriptif dengan jenis penelitian terapan (applied research). Metode kuantitatif deskriptif adalah metode yang dilakukan untuk menjawab persoalan-persoalan tentang keadaan atau kondisi yang terjadi sekarang dengan menggunakan data berupa angka-angka. ${ }^{44}$ Penelitian terapan dilakukan dengan tujuan menerapkan, menguji dan mengevaluasi kemampuan suatu teori yang diterapkan dalam memecahkan masalah-masalah praktis. ${ }^{45}$ Sedangkan berdasarkan sifatnya, penelitian ini merupakan penelitian eksplanatif yaitu penelitian yang menjelaskan kedudukan variabel-variabel yang diteliti serta hubungannya antara satu variabel dengan variabel lainnya, dalam hal ini hubungan yang saling mempengaruhi (interaktif). ${ }^{4}$

Penelitian ini dilakukan di Kabupaten Sambas Provinsi Kalimantan Barat, Kabupaten Sambas merupakan Kabupaten yang memiliki penduduk mayoritas muslim yaitu sebesar $84 \%$ dari total penduduk pada tahun 2015. Penelitian ini menggunakan pendekatan scientific (ilmiah-empiris), pendekatan ini mengemukakan bahwa ilmu diasosiasikan dengan objektivitas yaitu secara tegas pemisahan antara known (objek atau hal yang ingin diketahui dan diteliti) dan knower (subjek pelaku atau pengamat). Dimana tujuan penelitian pada pendekatan ini diarahkan pada upaya mengukur ada atau tidaknya pengaruh atau hubungan sebab akibat diantara dua variabel atau lebih dengan mengontrol pengaruh variabel lain, ${ }^{47}$ dalam hal ini menjelaskan hubungan antara perbankan syariah dan pertumbuhan ekonomi di Kabupaten Sambas.

Untuk mengetahui kontribusi perbankan syariah dalam hal ini dana pihak ketiga (DPK) dan pembiayaan terhadap pertumbuhan ekonomi (Produk Domestik Regional Bruto) Kabupaten Sambas, penelitian ini menggunakan data time series selama kurun waktu 2011-2017, yaitu berupa data sekunder statistik perbankan syariah yang dipublikasikan oleh Bank Indonesia (BI) dan Otoritas Jasa Keuangan (OJK), serta data Produk Domestik Regional Bruto (PDRB), yang dipublikasikan oleh Badan Pusat Statistik Kabupaten Sambas. ). Metode pengumpulan data yaitu observasi dan dokumentasi.

Untuk menjawab masalah dalam penelitian ini menggunakan analisis kontribusi. Analisis kontribusi dalam penelitian ini yaitu suatu alat analisis yang digunakan untuk mengetahui seberaps $Q X n \quad$ ntribusi yang dapat disumbangkan oleh perbankan syariah $1 \mathrm{Pn}=\frac{Q X n}{Q Y_{n}} \times 100 \%$ ketiga (DPK) dan pembiayaan terhadap pertumbuhan ekonor $Q Y n \quad$ Regional Bruto) di Kabupaten Sambas. Rumus yang digunaki ontribusi tersebut adalah sebagai berikut: ${ }^{48}$

Keterangan:

Pn : Kontribusi perbankan syariah (dana pihak ketiga dan pembiayaan) terhadap Pertumbuhan ekonomi (PDRB)

\footnotetext{
${ }^{44}$ Sugiono, Metode Penelitian Bisnis (Cet. 5; Jakarta: Alfabeta, 2015), h. 13. Lihat juga Moh.Kasiram, Metodologi Penelitian Kuantitatif dan Kualitatif (Malang: UIN Malang Press, 2008). h.149. Lihat juga Syofian Siregar, Metode Pmolitimn Kuantitatif: Dilengkapi dengan Perbandingan Perhitungan Manual \& SPSS (Jakarta: Kencan; 116308.

${ }^{45}$ Sugiono, Metode Penelitian Bisnis, 1

${ }^{46}$ Sugiono, Metode Penelitian Bisnis, h. 7.

${ }^{47}$ Prenada Cakra Buana Kusuma, Pendekatan-Pendekatan Keilmuan. https://Prenada.wordpress.com/2011/05/pendekatan-pendekatan-keilmuan (30 Mei 2017).

${ }^{48}$ Nugroho Budiyuwono, Pengantar Statistik Ekonomi dan Perusahaan (Yogyakarta: UPP-AMP YKPN, 2000), h. 160.
} 
QYn : Pertumbuhan ekonomi (total PDRB)

QXn : Dana pihak ketiga (DPK) dan Pembiayaan

$\mathrm{n} \quad$ : Tahun (periode) tertentu

Berdasarkan analisis tersebut akan diperoleh seberapa besar kontribusi perbankan syariah terhadap pertumbuhan ekonomi di Kabupaten Sambas.

\section{IV >. HASIL PENELITIAN DAN PEMBAHASAN}

Perkembangan ekonomi suatu daerah dapat dilihat melalui seberapa besar output yang dihasilkan penduduk wilayah tersebut selama jangka waktu tertentu. Output tersebut tercermin pada Produk Domestik Regional Bruto. Ada tiga metode dalam menghitung angka Produk Domestik Regional Bruto, yaitu metode produksi, pengeluaran, dan pendapatan. Nilai Produk Domestik Regional Bruto dalam penelitian ini menggunakan metode produksi.

Produk Domestik Regional Bruto dengan pendekatan produksi diperoleh melalui penjumlahan nilai tambah bruto (gross value added) dari semua sektor produksi. Perhitungan Produk Domestik Regional Bruto dengan pendekatan produksi dilakukan melalui penjumlahan semua sektor industri yang ada, termasuk di dalamnya adalah sektor bank dan lembaga keuangan lainnya. Pada dasarnya dari angka-angka tersebut sudah terlihat dengan jelas berapa kontribusi sektor perbankan dan lembaga keuangan lainnya terhadap Produk Domestik Regional Bruto. Namun, karena angka-angka tersebut masih bersifat umum dan belum ada pemisahan antara bank syariah dan bank konvensional, sehingga belum terukur dengan pasti berapa besarnya kontribusi perbankan syariah terhadap nilai Produk Domestik Regional Bruto Kabupaten Sambas.

Mengukur kinerja perbankan syariah sebagai lembaga intermediasi, dapat dilihat melalui kemampuan bank tersebut dalam menghimpun dana pihak ketiga (DPK) dan menyalurkannya kembali kepada masyarakat dalam bentuk pembiayaan. DPK bank syariah terdiri dari tabungan mudharabah, deposito mudharabah dengan berbagai termin, baik satu bulan; 3 bulan; 6 bulan; 12 bulan; dan lebih dari 12 bulan, serta giro wadiah. Sedangkan pembiayaan diberikan bisa dalam bentuk akad jual beli, bagi hasil, dan sewa.

Semakin banyak dana pihak ketiga (DPK) yang berhasil dihimpun dan pembiayaan yang disalurkan, diduga semakin memberi kontribusi positif terhadap pertumbuhan ekonomi di Kabupaten Sambas. Artinya, semakin banyak nasabah menyimpan dana di bank syariah, maka semakin banyak pula transaksi keuangan di bank syariah yang tercatat dalam Produk Domestik Regional Bruto. Begitu juga halnya dengan pembiayaan, semakin banyak pembiayaan yang disalurkan kepada masyarakat maka roda perekonomian akan dapat semakin bergerak karena pembiayaan merupakan salah satu sumber pendanaan untuk meningkatkan investasi.

Berdasarkan perhitungan analisis kontribusi dana pihak ketiga (DPK) dan pembiayaan perbankan syariah terhadap pertumbuhan ekonomi (Produk Domestik Regional Bruto) pada tahun 2011-2017 diperoleh hasil sebagai berikut:

\section{a. Kontribusi Dana Pihak Ketiga (DPK)}

Dana pihak ketiga (DPK) adalah dana yang berasal dari masyarakat atau nasabah yang terdiri dari giro, tabungan, simpanan berjangka, sertifikat deposito dan kewajiban segera lainnya. Semakin besar dana pihak ketiga yang tersedia, maka bank syariah akan lebih banyak menawarkan pembiayaan. ${ }^{49}$ Berdasarkan hasil analisis kontribusi diketahui

${ }^{49}$ Veithzal Rivai dan Arviyan Arifin, Islamic Banking (Jakarta: Bumi Aksara, 2010), h. 579. Lihat juga Slamet Riyadi, Banking Assets And Liability Management (Jakarta: LPFEUI, 2006), h. 20. 
seberapa besar kontribusi yang diberikan oleh dana pihak ketiga (DPK) dari perbankan syariah terhadap Produk Domestik Regional Bruto Kabupaten Sambas periode tahun 2011-2017 sebagai berikut:

Tabel 2. Kontribusi Dana Pihak Ketiga (DPK) terhadap Produk Domestik
Regional Bruto (PDRB) Kabupaten Sambas Tahun 2012-2017

\begin{tabular}{|c|c|c|c|c|}
\hline Tahun & $\begin{array}{c}\text { Total DPK } \\
(\mathrm{OXn})\end{array}$ & $\begin{array}{c}\text { Total PDRB } \\
\text { (OYn) }\end{array}$ & QXn : Qyn & $\begin{array}{c}\text { Kontribusi } \\
(\%)\end{array}$ \\
\hline 1 & 2 & 3 & $4=\mathrm{QXn}: \mathrm{QYn}$ & $5=(4) \times 100 \%$ \\
\hline 2011 & $19,000,000,000$ & $3,101,958,000,000$ & 0.006125164 & 0.61 \\
\hline 2012 & $27,000,000,000$ & $9,576,456,000,000$ & 0.002819415 & 0.28 \\
\hline 2013 & $29,000,000,000$ & $10,167,416,000,000$ & 0.002852249 & 0.29 \\
\hline 2014 & $34,000,000,000$ & $10,715,966,000,000$ & 0.003172836 & 0.32 \\
\hline 2015 & $41,000,000,000$ & $11,226,112,000,000$ & 0.003652199 & 0.37 \\
\hline 2016 & $58,000,000,000$ & $11,815,057,000,000$ & 0.00490899 & 0.49 \\
\hline 2017 & $105,000,000,000$ & $12,419,529,000,000$ & 0.008454427 & 0.85 \\
\hline \multicolumn{4}{|c|}{ Total } & 3.20 \\
\hline \multicolumn{4}{|c|}{ Rata-Rata } & 0.64 \\
\hline
\end{tabular}

Sumber: Data Sekunder diolah, 2018

Berdasarkan table 2 terlihat bahwa kontribusi dana pihak ketiga (DPK) yang telah di himpun oleh perbankan syariah terhadap Produk Domestik Regional Bruto pada tahun pertama kehadiran perbankan syariah di Kabupaten Sambas sebesar 0.61\%. Angka tersebut menurun drastis pada akhir tahun kedua yaitu menjadi $0.28 \%$, meski demikian pada tahun-tahun berikutnya terlihat adanya peningkatan kontribusi dana pihak ketiga terhadap Produk Domestik Regional Bruto walaupun dalam jumlah yang relatif kecil.

Hingga tahun ke tujuh kehadiran perbankan syariah di Kabupaten Sambas peningkatan yang terjadi belum mencapai angka seperti pada tahun pertama. Sehingga jika dilihat secara umum kontribusi dana pihak ketiga (DPK) selama kurun waktu tujuh tahun sejak kehadiran perbankan syariah di Kabupaten Sambas pada awal tahun 2011 hingga tahun 2017 masih sangat kecil yaitu sebesar 0.64\%. Angka tersebut jauh tertinggal jika dibandingkan dengan kontribusi dana pihak ketiga (DPK) dari perbankan konvensional yaitu sebesar $27.02 \%$ terhadap Produk Domestik Regional Bruto Kabupaten Sambas.

Berdasarkan table 2 dapat juga dilihat bahwa peningkaan total dana pihak ketiga (DPK) perbankan syariah selama kurun waktu enam tahun mengalami peningkatan yang sangat kecil sehingga kontribusi yang disumbangkan juga relative kecil. Selain itu dapat juga dilihat adanya peningkatan yang cukup drastis pada Produk Domestik Regional Bruto Kabupaten Sambas pada tahun 2011 sebesar 3.1 triliun menjadi 9.6 triliun pada tahun 2012. Peningkatan yang cukup drastis tersebut tidak diikuti oleh peningkatan total dana pihak ketiga (DPK) yang berhasil dihimpun oleh perbankan syariah, sehingga menyebabkan kecilnya kontribusi dana pihak ketiga (DPK) terhadap Produk Domestik Regional Bruto Kabupaten Sambas. 


\section{b. Kontribusi Pembiayaan}

Salah satu penyumbang pendapatan terbesar bagi bank syariah adalah dengan menjalankan aktivitas pembiayaan. Pembiayaan adalah pendanaan yang diberikan oleh suatu pihak kepada pihak lain untuk mendukung investasi yang telah direncanakan, baik dilakukan sendiri maupun lembaga. ${ }^{50}$ Berdasarkan hasil analisis kontribusi diketahui seberapa besar kontribusi yang disumbangkan oleh pembiayaan perbankan syariah terhadap Produk Domestik Regional Bruto Kabupaten Sambas periode tahun 2011-2017 sebagai berikut:

Tabel 3. Kontribusi Pembiayaan terhadap Produk Domestik Regional Bruto (PDRB) Kabupaten Sambas Tahun 2011-2017

\begin{tabular}{|c|c|c|c|c|}
\hline \multirow[t]{2}{*}{ Tahun } & $\begin{array}{c}\text { Total } \\
\text { Pembiayaan }\end{array}$ & Total PDRB & \multirow[t]{2}{*}{ QXn : QYn } & \multirow[t]{2}{*}{$\begin{array}{c}\text { Kontribusi } \\
(\%)\end{array}$} \\
\hline & $(\mathbf{Q X n})$ & $(\mathbf{Q Y n})$ & & \\
\hline 1 & 2 & 3 & 4 = Qxn:Qyn & $5=(4) \times 100 \%$ \\
\hline 2011 & $17,000,000,000$ & $3,101,958,000,000$ & 0.005480409 & 0.55 \\
\hline 2012 & $44,000,000,000$ & $9,576,456,000,000$ & 0.004594602 & 0.46 \\
\hline 2013 & $63,000,000,000$ & $10,167,416,000,000$ & 0.006196265 & 0.62 \\
\hline 2014 & $57,000,000,000$ & $10,715,966,000,000$ & 0.005319166 & 0.53 \\
\hline 2015 & $62,000,000,000$ & $11,226,112,000,000$ & 0.005522838 & 0.55 \\
\hline 2016 & $122,000,000,000$ & $11,815,057,000,000$ & 0.010325807 & 1.03 \\
\hline 2017 & $261,000,000,000$ & $12,419,529,000,000$ & 0.02101529 & 2.10 \\
\hline \multicolumn{4}{|c|}{ Total } & 5.83 \\
\hline \multicolumn{4}{|c|}{ Rata-Rata } & 1.17 \\
\hline
\end{tabular}

Sumber: Data Sekunder diolah, 2018

Berdasarkan tabel 3. terlihat bahwa kontribusi pembiayaan yang telah disalurkan oleh perbankan syariah terhadap Produk Domestik Regional Bruto selama kurun waktu enam tahun sejak 2011 sampai 2017 menunjukkan angka yang agak fluktuatif, dimana pada tahun pertama kehadiran perbankan syariah di Kabupaten Sambas mampu berkontribusi sebesar $0.55 \%$, kemudian sedikit menurun pada tahun kedua dan mengalami sedikit peningkatan pada tahun ketiga, demikian seterusnya hingga tahun keenam. Pada tahun keenam kontribusi pembiayaan terhadap Produk Domestik Regional Bruto menunjukkan angka yang cukup menggembirakan jika dibandingkan dengan tahun-tahun sebelumnya, yaitu mampu mencapai angka $1.03 \%$ dan terus meningkat pada tahun ke tujuh menjadi $2.10 \%$.

Jika dilihat secara umum kontribusi pembiayaan yang telah disalurkan oleh perbankan syariah selama kurun waktu enam tahun sejak kehadiran perbankan syariah di Kabupaten Sambas pada awal tahun 2011 hingga tahun 2017 masih sangat kecil yaitu

\footnotetext{
${ }^{50}$ Veithzal Rivai dan Arviyan Arifin, Islamic Banking, h. 681.
} 
sebesar $1.81 \%$. Angka tersebut jauh tertinggal jika dibandingkan dengan kontribusi pembiayaan yang berhasil disalurkan oleh perbankan konvensional yaitu sebesar 34.39\% terhadap Produk Domestik Regional Bruto Kabupaten Sambas.

Berdasarkan table 3. dapat juga dilihat bahwa peningkaan total pembiayaan perbankan syariah selama kurun waktu enam tahun mengalami fluktuatif sehingga kontribusi yang disumbangkan juga relatif fluktuatif. Selain itu dapat juga dilihat adanya peningkatan yang cukup drastis pada Produk Domestik Regional Bruto Kabupaten Sambas pada tahun 2011 sebesar 3.1 triliun menjadi 9.6 triliun pada tahun 2012. Peningkatan yang cukup drastis tersebut tidak diikuti oleh peningkatan total pembiayaan yang berhasil disalurkan oleh perbankan syariah, sehingga menyebabkan kecilnya kontribusi total pembiayaan terhadap Produk Domestik Regional Bruto Kabupaten Sambas.

Itu artinya kehadiran perbankan syariah di Kabupaten Sambas selama kurang lebih enam tahun belum mampu menarik minat masyarakat untuk menyimpan dana dan mengajukan bantuan permodalan kepada perbankan syariah. Perbankan syariah masih memerlukan upaya yang lebih kuat untuk bersaing dengan perbankan konvensional yang telah hadir lebih dahulu di tengah-tengah masyarakat Kabupaten Sambas. Walaupun demikian, dari hasil tersebut fungsi intermediasi perbankan syariah di Kabupaten Sambas telah berjalan dengan baik meskipun dalam jumlah yang relatif kecil. Ketika dana pihak ketiga (DPK) telah terkumpul, pihak perbankan syariah segera menyalurkan dana tersebut kedalam bentuk pembiayaan. Sehingga roda perekonomian yang didorong oleh pembiayaan dari perbankan syariah akan turut meningkatkan Produk Domestik Regional Bruto Kabupaten Sambas. Dengan meningkatnya Produk Domestik Regional Bruto maka itu artinya pendapatan masyarakat Kabupaten Sambas semakin meningkat, dimana salah satunya dialokasikan kembali kepada perbankan syariah dalam bentuk simpanan.

Hasil analisis kontribusi dalam penelitian ini sejalan dengan hasil penelitian yang dilakukan oleh Rama. Dengan pendekatan kausalitas granger, Rama menyimpulkan bahwa perbankan syariah yang direpresentasikan melalui total pembiayaan dan DPK secara positif berkontribusi terhadap pertumbuhan ekonomi dan riil output di Indonesia dalam jangka panjang. Selain itu, penelitian ini menjadi komplementer dari dua hasil penelitian terdahulu dalam lingkup daerah yaitu penelitian yang dilakukan oleh Antonio Syafii dan Rusydiana. Penelitian tersebut mendeskripsikan bahwa keberadaan bank syariah di daerah membawa implikasi bagi pembangunan ekonomi setempat karena adanya aktivitas intermediasi yang dilakukan perbankan syariah yang menyalurkan dana dari pihak yang surplus ke pada pihak yang shortage. ${ }^{51}$ Serta penelitian yang dilakukan oleh Zaini Ibrahim yang menyatakan bahwa peningkatan ekonomi di Banten dipengaruhi oleh pertumbuhan sektor keuangan, termasuk di dalamnya ada perbankan syariah. Hal tersebut menegaskan bahwa fungsi intermediasi perbankan syariah telah berjalan dengan baik. ${ }^{52}$

Penelitian lain yang juga sejalan dengan penelitian ini yaitu penelitian yang dilakukan oleh Andriansyah. Penelitian tersebut melakukan analisis pada laporan keuangan perbankan syariah selama periode 2005 sampai 2009 yang menyimpulkan bahwa melalui nilai rata-rata FDR (financing to deposit ratio) yang mencapai 99,63\%, menggambarkan perbankan syariah menjalankan fungsi intermediasi dengan baik. Hanya saja garapan pembiayaannya belum menyentuh pada sektor primer, misalnya pertanian dan perkebunan. ${ }^{53}$

\section{PENUTUP}

${ }^{51}$ Syafi'i Antonio dan Aam S. Rusydiana, "Peran Ekonomi Syariah dalam Pembangunan Ekonomi”, Jurnal Multikultural \& Multireligius IX, No. 33, (2010): h. 54-55.

${ }^{52}$ Zaini Ibrahim, "Kontribusi Perbankan Syariah Terhadap Perekonomian Banten", Jurnal Islamiconomic 6, No.1, (2015): h. 125-126.

${ }^{53}$ Yuli Adriansyah, "Kinerja Keuangan Perbankan Syariah dan Kontribusinya Bagi Pembangunan Nasional”, Jurnal Ekonomi Islam La_Riba III, No. 2, (2009): h. 193-195. 
Kontribusi dana pihak ketiga (DPK) terhadap pertumbuhan ekonomi (Produk Domestik Regional Bruto) Kabupaten Sambas adalah sebesar 0.64\%. Angka tersebut dapat dikatakan sangat kecil jika dibandingkan dengan kontribusi dana pihak ketiga yang dapat dihimpun oleh perbankan konvensional yaitu sebesar 27.02\%. Demikian juga halnya dengan kontribusi pembiayaan terhadap pertumbuhan ekonomi (Produk Domestik Regional Bruto) Kabupaten Sambas, juga menunjukkan angka yang relatif kecil yaitu sebesar $1.17 \%$, jauh dibawah kontribusi pembiayaan yang berhasil disalurkan oleh perbankan konvensional yaitu sebesar 34.39\%. Secara umum kontribusi perbankan syariah melalui total dana pihak ketiga (DPK) dan total pembiayaan terhadap pertumbuhan ekonomi (Produk Domestik Regional Bruto) Kabupaten Sambas hanya sebesar $1.81 \%$ jauh dibawah kontribusi dana pihak ketiga (DPK) dan pembiayaan perbankan konvensional yaitu sebesar $61.41 \%$. Diharapkan agar hasil penelitian ini dapat menjadi bahan pertimbangan bagi pihak perbankan syariah dalam mengambil keputusan terutama dalam mengoptimalkan penghimpunan dana pihak ketiga (DPK) dan penyaluran pembiayaan, sehingga dapat lebih berkontribusi terhadap pertumbuhan ekonomi (Produk Domestik Regional Bruto) Kabupaten Sambas.

\section{DAFTAR PUSTAKA}

Adriansyah, Yuli "Kinerja Keuangan Perbankan Syariah dan Kontribusinya Bagi Pembangunan Nasional", Jurnal Ekonomi Islam La_Riba III, No. 2, (2009).

Anshori, Perbankan Syariah di Indonesia. Yogyakarta: Gajah Mada University Press. 2007.

Antonio, Muhammad Syafi'i. Bank Syariah Dari Teori ke Praktik. Jakarta: Gema Insani Press, 2001

Antonio, Syafi'i. dan Aam S. Rusydiana, "Peran Ekonomi Syariah dalam Pembangunan Ekonomi”, Jurnal Multikultural \& Multireligius IX, No. 33, (2010).

Ascarya, Akad dan Produk Bank Syariah. Jakarta: PT. RajaGrafindo Persada, 2008.

Badan Pusat Statistik, Produk Domestik Regional Bruto (Lapangan Usaha), https://www.bps.go.id/Subjek/view/id/52, (07 Maret 2016).

Bank Indonesia, "Statistik Perbankan Syariah", Publikasi desember 2012 dan Otoritas Jasa Keuangan, "Statistik Perbankan Syariah", Publikasi desember 2016.

Buana Kusuma, Prenada Cakra. Pendekatan-Pendekatan Keilmuan. https://Prenada.wordpress.com/2011/05/pendekatan-pendekatan-keilmuan (30 Mei 2017).

Budiyuwono, Nugroho. Pengantar Statistik Ekonomi dan Perusahaan. Yogyakarta: UPP-AMP YKPN, 2000.

Dumairy, Perekonomian Indonesia. Jakarta: Erlangga, 1996.

Ibrahim, Zaini. "Kontribusi Perbankan Syariah Terhadap Perekonomian Banten", Jurnal Islamiconomic 6, No.1, (2015).

Ismail, Manajemen Perbankan: Dari Teori Menuju Aplikasi. Jakarta: Kencana. 2010.

Jhingan, M.L. The Economics of Development and Planning, terj. D. Guritno, Ekonomi Pembangunan dan Perencanaan. Jakarta: Rajawali Pers, 2016.

Karim, Adiwarman. Bank Islam Analisis Fiqih dan Keuangan. Jakarta: PT.RajaGrafindo Persada, 2004.

Kasiram, Moh. Metodologi Penelitian Kuantitatif dan Kualitatif. Malang: UIN Malang Press, 2008. 
Kementerian Agama RI, Al-Qur'an dan Terjemahnya. Yogyakarta: UII Press, 1999.

Lewis, Mervyn K. dan Latifa M. Algaoud, Perbankan Syari'ah: Prinsip, Praktik, dan Prospek, trj. Burhan Subrata. Jakarta: Serambi Ilmu Semesta, 2007.

Martono, Bank Lembaga Keuangan Lainnya. Yogyakarta: BPFE UGM, 2003.

Muhammad, Manajemen Pembiayaan Bank Syariah. Yogyakarta: UPP AMP YKPN, 2002.

Muhammad, Manajemen Bank Syariah. Yogyakarta: UPP STIM YKPN, 2011.

Muhammad, Manajemen Dana Bank Syariah. Jakarta: PT. RajaGrafindo Persada, 2017.

Pohan, Aulia. Kerangka Kebijakan Moneter dan Implementasinya di Indonesia. Jakarta: PT. RajaGrafindo Persada, 2008.

Pohan, Aulia. Potret Kebijakan Moneter Indonesia. Jakarta: PT. RajaGrafindo Persada, 2008.

Rahardja, Prathama dan Mandala Manurung, "Teori Ekonomi Makro: Suatu Pengantar", dalam Zaini Ibrahim, "Kontribusi Perbankan Syariah Terhadap Perekonomian Banten", Jurnal Islamiconomic 6, No.1, (2015)

Rama, Ali. "Analisis Kontribusi Perbankan Syariah terhadap Pertumbuhan Ekonomi Indonesia". http://lisensiuinjkt.file.wordpress.com. (14 Juli 2015)

Republi Indonesia, Undang-Undang No.10 tahun 1998 Perubahan atas UndangUndang Nomor 7 Tahun 1992 tentang Perbankan, pasal 1, ayat5.

Rivai, Veithzal. dan Arviyan Arifin, Islamic Banking. Jakarta: Bumi Aksara, 2010.

Riyadi, Slamet. Banking Assets And Liability Management. Jakarta: LPFEUI, 2006.

Saberan, H. Produk Domestik Regional Bruto. Jakarta: Rajawali, 2002.

Siregar, Syofian. Metode Penelitian Kuantitatif: Dilengkapi dengan Perbandingan Perhitungan Manual \& SPSS. Jakarta: Kencana, 2013.

Shihab, M. Quraish. Tafsir Al-Mishbah: Pesan Kesan dan Keserasian Al-Qur'an. Jakarta: Lentera Hati, 2002.

Sugiono, Metode Penelitian Bisnis. Cet. 5; Jakarta: Alfabeta, 2015.

Sukirno, Sudono. Pengantar Teori Mikroekonomi. Jakarta: RajaGrafindo Persada, 2003.

Tarigan, R. Ekonomi Regional: Teori dan Aplikasi. Jakarta: Bumi Aksara. 2005.

Wibowo, Edy, dkk, Mengapa Memilih Bank Syariah? Cet. I; Bogor: Ghalia Indonesia, 2005.

Yusdani, "Perbankan Syariah Berbasis Floating Market", Jurnal Millah IV, No.2, (2005). 